\title{
IMPACT OF ARTISANAL TECHNOLOGIES ON THE QUALITY INDICES OF THE COZONAC
}

\author{
Rodica Siminiuc, Dinu Țurcanu \\ Technical University of Moldova, Chisinau, Republic of Moldova
}

\section{KEY WORDS:}

cozonac, sourdough, fermentation, artisanal technologies, soriz

(Sorghum oryzoidum),

nutritional aspects

\begin{abstract}
The research focused on studying the impact of sourdough with spontaneous flora (SSF) (obtained also from gluten-free flour) and artizanal technologies on the quality indices of cozonac - a traditional pastry product. Physico-chemical and microbiological indices were analyzed, as well as glycemic index (GI) of cozonac samples with different fermentation agents. The experimental results showed that the GI of the cozonac samples have similar values, being between GI $=68$ and GI $=71$. Respectively, cozonac with SSF samples can be classified in the category of foods with moderate GI, and cozonac with commercial yeast (CY) - in the category of foods with high GI. Digestibility indices for all samples reached values between $72 \%$ and $76 \%$. The sensory profiles of baked cozonacs were analyzed descriptively by the panel members, and the results showed that all cozonac samples were characterized by slightly acid taste, with specific and pleasant flavors.

However, it seems that a long fermentation of the dough, even if CY is used as a fermenting agent, leads to the formation of quality indices of the dough and cozonac, very close to the products obtained only with SSF.

The use of SSF from sorghum flour would be an alternative in the development of gluten free bakery and pastry products using artisanal technologies.
\end{abstract}

\section{Introduction}

Technologies inspired by nature for a sustainable future! These are the trends of the modern consumer: quality products based on "bioinspired" technologies, obtained from natural and quality materials. Trends that are found in the first objectives of the 2030 Agenda for Sustainable Development are a challenge for a healthy future! Consumer concern about traditional artisanal products is on the rise [1]. This situation generates a demand for agricultural or food products with certain identifiable characteristics, in particular as regards their geographical origin. Currently, there is an upward trend of consumers to benefit from products not only with optimal organoleptic properties, but also with increased nutritional values.

Symbol of the fundamental holidays of Christianity, the cozonac also has the symbolism of bread: bread, in its Eucharistic form, refers to active life. And the active principle of fermentation becomes a symbol of spiritual transformation. Cozonac is a sweet bread, traditional in the Republic of Moldova, Romania, Bulgaria (kozunak), being traditionally cooked for Easter or Christmas. A similar sweet is "panettone" in Italy, in Russia "kulichi", in Ukraine and Belarus "paska". According to some sources, the cake in the form and recipe known in the Republic of Moldova and Romania by all of us, is a Romanian invention.

The Bulgarian researcher, ethnologist Donka Sabotinova, says that he arrived in Bulgaria around 1915, brought from Romania by merchants around the Easter holidays, traded under the name of kozunak. It seems that the name cozonac comes

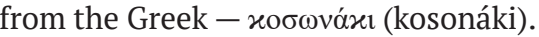

Cozonac in its simplest form is a sugar-sweetened flour mixed with eggs, milk, fat and a fermenting agent, but for every country and region there is a huge variety of recipes.

Currently, sourdough with spontaneous flora (SSF) is used more and more frequently in the production of artisanal products such as: panettone, pandoro, cozonac, typical regional bakery products, bringing rheological, sensory and nutritional benefits, as well as extending the shelf-life of the product. Sourdough is seen as an intermediate transition between the mixture and the final product, in which the active metabolic microorganisms modify the original characters of the initial ingredients (water and flour), a process that stimulated the interests of researchers [2,3].

There are multiple methods of making SSF. In general, this involves a mixture of water and flour and possibly salt and sugar, which is left to ferment for about 24 hours. At this stage the yeasts and lactic bacteria, naturally present in the flour, produce $\mathrm{CO} 2$ and organic acids. Reducing the $\mathrm{pH}$ activates the flour proteases, which, together with the hydrolytic enzymes of the bacteria, act on gluten, leading to a reduction in the consistency (fluidization) of the mixture. In the second stage, the mixture is refreshed to ensure oxygenation and provide a new nutrient substrate for microorganisms. The refreshments are repeated at certain intervals, until the fermentation capacity is kept constant. It is considered that the optimal time to make the refresh is determined by increasing the volume of the mixture about 3-4 times compared to the initial volume [4].

Regardless of the procedure involved, the microbiological composition of the SSF is represented by a mixture of lactic bacteria and yeasts in a ratio of 100: 1, with respective values of 109 and $107 \mathrm{CFU} / \mathrm{g}[4,5]$.

It is considered that the use of SSF in the manufacture of bakery and pastry products has many advantages:

$\square$ improving the rheological properties of the dough (by accumulating metabolites, respectively amino acids);

$\square$ obtaining products with a better flavor and texture compared to products fermented only with commercial yeast;

$\square$ improving the nutritional values of products by increasing the bioavailability of minerals and reducing the glycemic index;

$\square$ increasing the shelf life of the products, through the inhibitory effect on molds possessed by organic acids, formed during fermentation;

low $\mathrm{pH}$ inhibits amylase activity, so that starch degradation is avoided;

$\square$ fermentation with SSF improves water binding capacity, starch swelling and solubility of pentosans etc. 
The aim of the research is to study the impact of artisanal technologies (the use of SSF and the long fermentation time) on the quality indices of cozonac - a traditional product of the Moldovan people.

\section{Materials and methods}

The quality of finished products depends on several factors, among which the most important are: the quality of the raw material and the technological process. For the preparation of SSF, as well as cozonacs, 2 types of local flour were used:

$\square$ high quality wheat flour (origin: Măgdăcești village)

$\square$ sorghum flour (Sorghum Oryzoidum) (SC „Andigor”).

The quality indices of the flours used are presented in Table 1.

Physico-chemical indices of flour samples [6,7]

Table 1

\begin{tabular}{lcc}
\hline \multicolumn{1}{c}{ Quality index } & Wheat flour & Soriz flour \\
\hline Acidity, (degrees) & $2.8 \pm 0.2$ & $3.2 \pm 0.3$ \\
\hline Dry substance, \% & $13.45 \pm 0.3$ & $12.7 \pm 0.2$ \\
\hline Wet gluten, (\%) & $26.18 \pm 0.7$ & - \\
\hline Dry gluten, (\%) & $61.0 \pm 1.5$ & - \\
\hline Hydration capacity, (\%) & $51.0 \pm 0.5$ & $100.0 \pm 1.0$ \\
\hline Maltose index, g / 100 g & $0.5 \pm 0.2$ & $2.3 \pm 0.1$
\end{tabular}

The research was performed on the following cake samples:

$\square$ Cozonac of wheat flour with commercial yeast (CY) - standard sample;

$\square$ Cozonac of wheat flour with sourdough with spontaneous flora (SSF) of wheat flour;

$\square$ Cozonac of wheat flour with sourdough with spontaneous flora (SSF) of soriz flour.

SSF were obtained in laboratory conditions, by mixing wheat / soriz flour with water in proportions of 50/50. The mixture obtained, being subjected to fermentation under the influence of spontaneous flowering for 66 hours with periodic refreshments (Figure 1).

In order to characterize and evaluate the quality of cozonacs with SSF, the parameters mentioned in Table 2 were identified.
Table 2

Methods for determining the quality indices of cozonac

\begin{tabular}{ll}
\hline \multicolumn{1}{c}{ Quality indices } & \multicolumn{1}{c}{ References } \\
\hline Loss of mass at baking & GOST 21094-75 [7] \\
\hline Moisture & GOST 21094-75 [9] \\
\hline $\mathrm{pH}$ & 26-PH-metru-WTW-Inolab-ph-7110 \\
\hline Porosity and elasticity of the crumb & GOST 5669-96 [10] \\
\hline $\begin{array}{l}\text { Microbiological indices (the total } \\
\text { number of yeasts and molds) }\end{array}$ & GOST 10444.1 2-88 [11] \\
\hline Glycemic index (in vivo method) & ISO 26642-2010 [12]. \\
\hline $\begin{array}{l}\text { Protein digestibility in vitro } \\
\text { Sensory indices }\end{array}$ & Sudeash, J. et al. [13] \\
\hline
\end{tabular}

The glycemic index of the tested samples was determined in vivo by monitoring the blood glucose level of the experiment participants until and after the consumption of the researched food products, according to ISO 26642: 2010 [12]. The glycemic response after consumption of each product was compared with that stimulated by glucose consumption as a reference substance [15]. The data obtained were used to construct the glycemic response curves of the participants after consuming the tested samples. The area of the surface under curves was determined by mathematical method with the help of AutoCAD through the program "Inquiry" which calculates exactly the area of the surface. Finally, the glycemic index was calculated according to the formula:

$$
G I=\frac{S a}{S g} 100
$$

where:

GI - glycemic index of the analyzed food;

$\mathrm{S} a$ - the surface area under the glycemic curve of the studied food;

$\mathrm{Sg}$ - the surface area under the glucose curve of glucose.

The blood glucose in the capillary blood of the experiment subjects was determined by the endpoint glucose oxidase method at the biochemical analyzer "STAT-FAX 1904" [16]. Principle of the method: Glucose, under the action of glucosidase, is con-

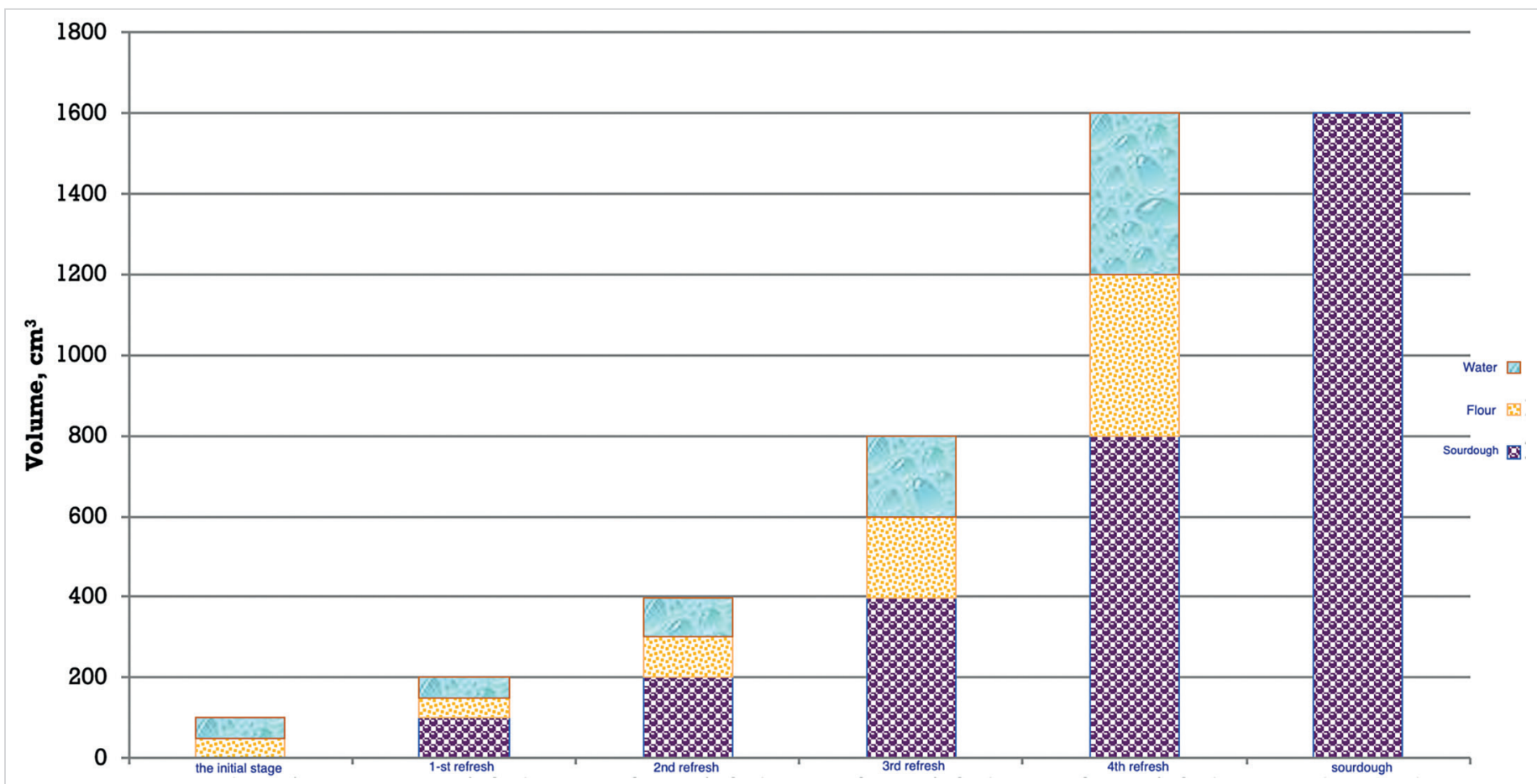

Figure 1. General scheme for obtaining SSF 
verted into gluconic acid. The resulting $\mathrm{H} 2 \mathrm{O} 2$ will be decomposed by peroxidase, following the reaction in which the Trinder indicator (phenol and 4 amino antipyrine) also participates, resulting in a red-colored condensation product with maximum absorption at $\lambda=505 \mathrm{~nm}$. Extinction is directly proportional to glucose concentration [17].

\section{Results and discussion}

Cozonac, a typical traditional product, symbol of Christmas and Easter, once cooked only by artisanal technologies, now broadcast at industrial level, is characterized by a strong spongy core, consistency and flavor unmistakable. The cozonacs were obtained from the culinary technology laboratory of the Food and Nutrition Department, Technical University of Moldova, by the indirect method according to the technological scheme (Figure 2):

\subsection{Physico-chemical indices}

The average humidity values of the cozonac samples were about: $25 \%$ for the cozonac with CY, $26 \%$ for the cozonac with SSF from wheat flour and $23 \%$ for the cozonac with SSF from soriz flour. In the last stage of the technological process, the product undergoes physical / structural and biochemical changes, which are crucial for acquiring rheological, sensory and nutritional characteristics. The samples obtained, after baking, were cooled to $\mathrm{t}-18-20 \mathrm{C}$ for 8 hours, to strengthen the structure of the product after which they were subjected to determinations [18].

The values of mass losses at baking were close to all samples, being between 10-13\% (Figure 3). The smallest being in the samples of soriz flour, probably due to the specific feature of agglutinative flours to retain a larger amount of water. The loss of mass results from the loss of moisture, from the outer layers of the dough. In the literature these losses are between 6-22\% [4, 19].

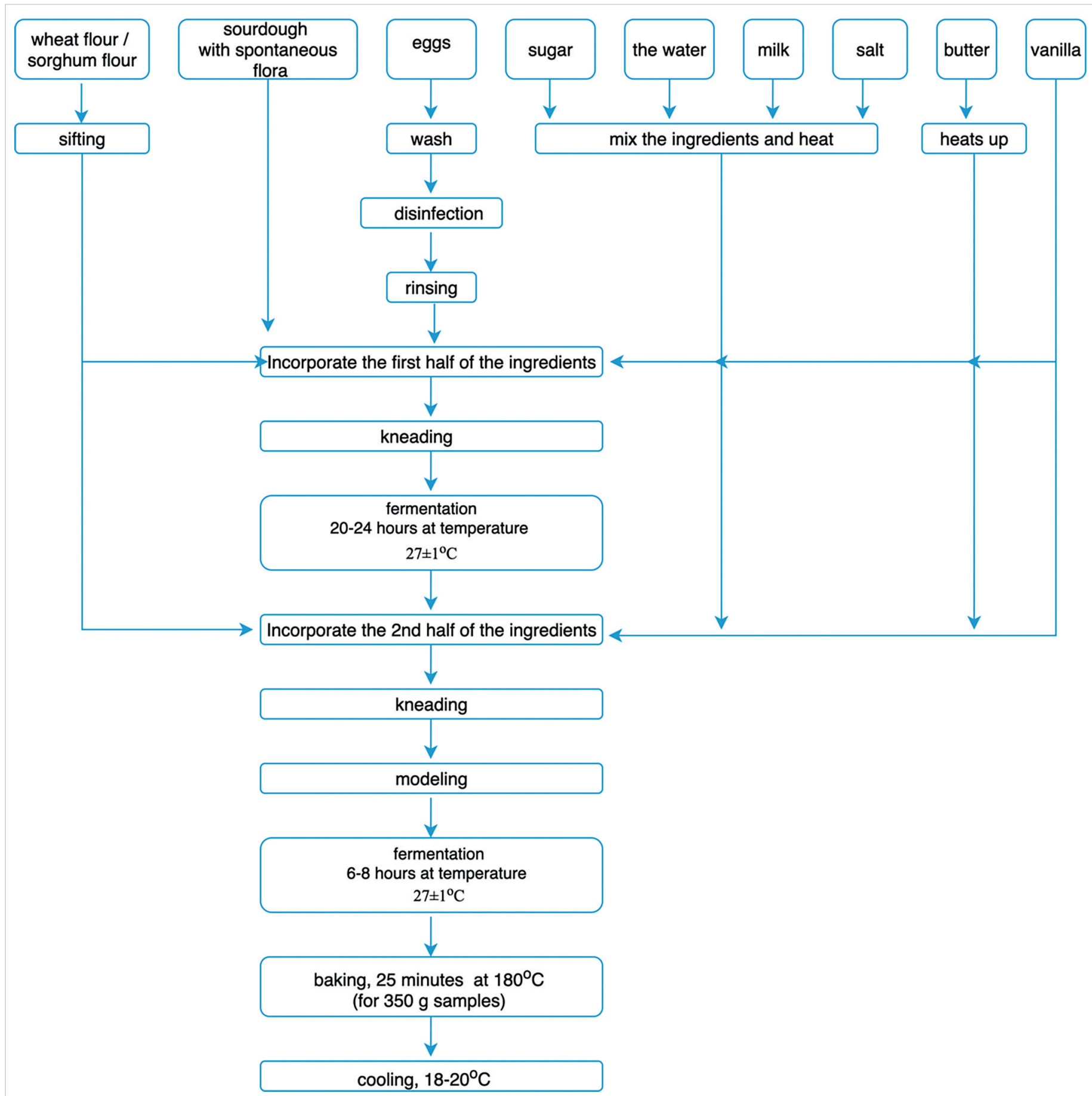

Figure 2. General technological scheme for obtaining the cozonac 
The porosity of the investigated cozonac samples was between $85 \%$ (for the wheat SSF cozonac) and 79\% (for the sorghum SSF cozonac) (Figure 4). The porosity of the SSF cozonac sample from wheat flour is $1 \%$ higher than the standard sample (CY cozonac) (Figure 4).

The elasticity was between $76 \div 96 \%$, the most elastic being the cozonac with SSF from wheat (96\%), and the least elasticity was the cozonac with SSF from soriz (76\%), probably due to the gluten free properties of the sorghum flour from which the SSF was obtained. However, the differences between values, for all cozonac samples, are not considerable and could be explained by the formation of acids in the fermentation process, and as a result there is swelling and development of gluten proteins, which potentially contributes to a more efficient intercalation within the elastic network (Figure 5).

The $\mathrm{pH}$ was 4.46 in the CY cozonac, in the wheat flour SSF cozonac- $\mathrm{pH}=4.52$ and $\mathrm{pH}=4.54$, respectively, in the sorghum SSF cozonac and is due to organic acids, in particular lactic acid formed in the fermentation process of SSF and subsequently of the dough.

The acidity values for all samples are close, because even in doughs fermented with commercial yeast, the acidification is due primarily to the lactic acid produced by the lactic microbiota when the fermentation exceeds 8-12 hours and, secondly, to the production of succinic acid by Saccharomyces cerevisiae $[20,21,22]$. The $\mathrm{pH}$ of the cozonac samples decreased slowly during the storage period (30 days) to $4.40,4.49$ and 4.52 , respectively. The results obtained are close to the values for artisanal Italian panettone whose $\mathrm{pH}$ initially had values of 4.54 and decreased to 4.12 after 180 days of storage [19].

\subsection{Microbiological indices}

To determine the total number of yeasts and molds, inoculation was performed on Yeast Extract Glucose Chloramphenicol Agar (YGCA), followed by incubation under aerobic conditions at $25 \mathrm{oC}$ for 5 days. The results are shown in Table 3 and are characteristic for artisanal bakery products with SSF [19].

Microbiological indices of cozonac samples

\begin{tabular}{|lcc|}
\hline \multicolumn{1}{c}{ Cozonac samples } & $\begin{array}{c}\text { the total number of yeasts } \\
\text { and molds, CFU }\end{array}$ \\
\hline 1. & cozonac with commercial yeast & $0.78 \pm 0.8$ \\
\hline 2. & cozonac with SSF of wheat flour & $0.79 \pm 1.0$ \\
\hline 3. & cozonac with SSF of soriz flour & $0.78 \pm 0.9$ \\
\hline
\end{tabular}

\subsection{Nutritional indices}

In vitro protein digestibility. Heat treatment beyond $95^{\circ} \mathrm{C}$ is considered to have both a beneficial and inhibitory influence on

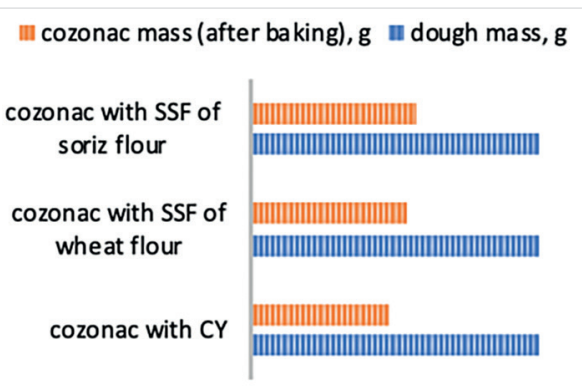

$\begin{array}{llllll}260 & 280 & 300 & 320 & 340 & 360\end{array}$

Figure 3. Baking mass losses

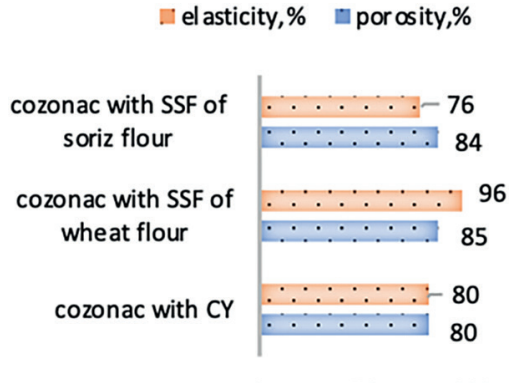

$\begin{array}{llll}0 & 50 \quad 100 \quad 150\end{array}$

Figure 4. The impact of SSF on the elasticity and porosity of cozonacs

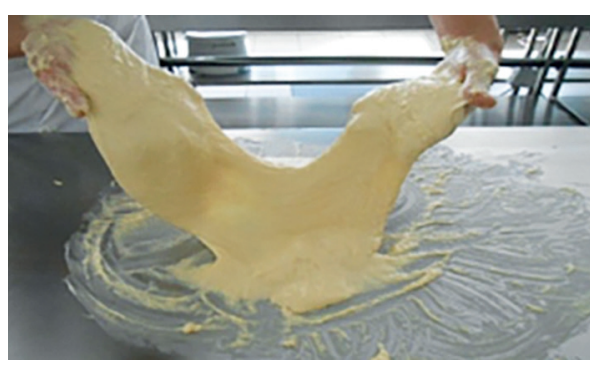

Kneading (40 min) after incorporating the first half of the ingredients (formation of the gluten network)

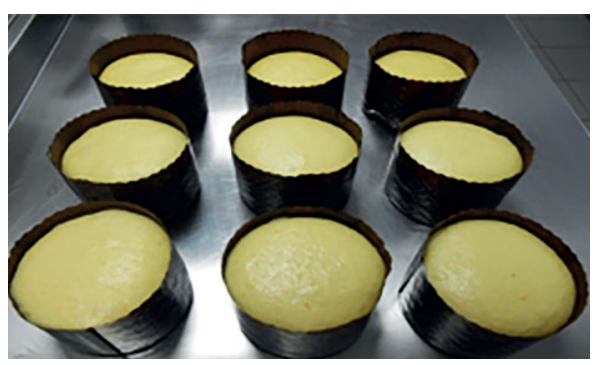

Second fermentation (after 6-8 hours at $T=27 \pm{ }^{\circ} \mathrm{C}$ )

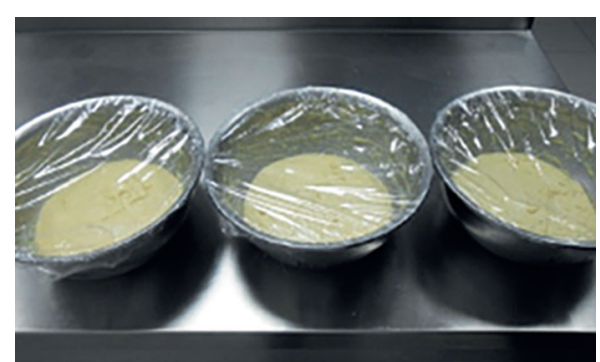

Initiation of the first fermentation (20-24 hours)

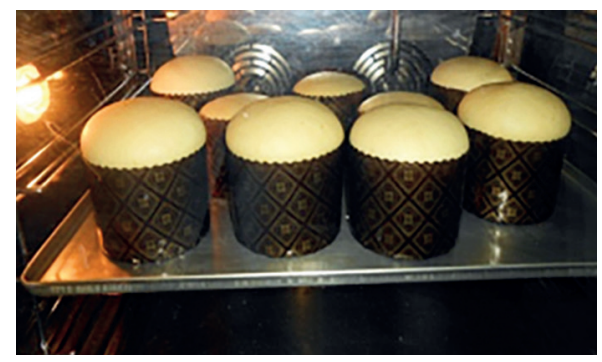

Baking at $180^{\circ} \mathrm{C}$

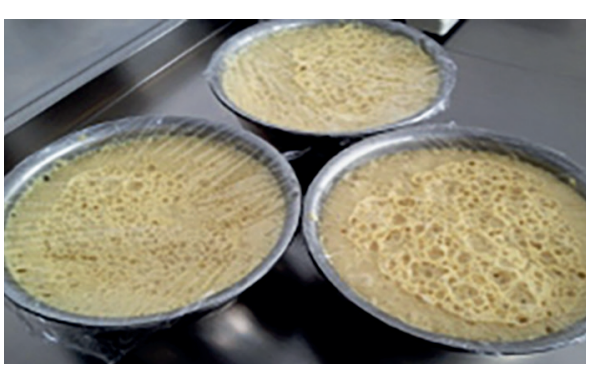

After 24 hours of fermentation

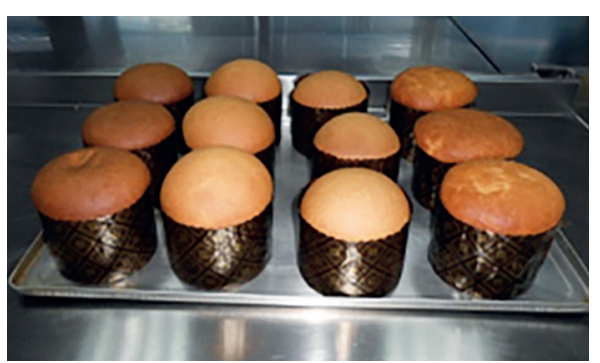

Cozonac samples after baking

Figure 3. Images of the process of obtaining cozonacs 
protein digestibility. Beneficial effects include inactivation of digestive enzyme inhibitors and development of heat-induced protein structure, while aggregation of denatured proteins resulting from new molecular interactions (little or no attack of digestive enzymes) and have the opposite effect. It is also considered that a major impact on digestibility has a microstructure of gels, formed by proteins, starch, etc. which affects the diffusion of enzymes in the food system and therefore the enzymatic degradation of proteins $[23,24]$. The digestibility values (with trypsin) of the cozonac samples reached values between 72 and $76 \%$ (Table 4 ).

\begin{tabular}{lcc} 
& \multicolumn{2}{c}{ Degree of digestibility of cozonac proteins } \\
\hline & Cozonac samples & Digestibility, \% \\
\hline 1. & cozonac with commercial yeast & $72 \pm 1.0$ \\
\hline 2. & cozonac with SSF of wheat flour & $76 \pm 1.0$ \\
\hline 3. & cozonac with SSF of soriz flour & $75 \pm 1.6$
\end{tabular}

The values of the digestibility indices of the cozonacs could be explained by the fact that all the samples (although they had different fermentation agents), took place in identical conditions of time and environment. In the literature there are indices of protein degistibility in bakery products, with values between 79.96 and 80.62 [25].

Glycemic index. The average pre-prandial glycemia of participants in the experiment was in the optimal range of $3.8 \pm 0.8 \mathrm{mmol} / \mathrm{l}$. After consuming the samples examined maximum glycemia was reached over 30 minutes.

The experimental results showed that the GI of the cozonac samples have similar values, being between $\mathrm{GI}=68$ and $\mathrm{GI}=71$ (Figure 6). Although GI values do not differ significantly, cozonacs with SSF can be included in the category of foods with mod- erate GI, and cozonacs with CY - in the category of foods with high GI $[15,26,27,28]$. However, experiments on GI are required, given the multitude of factors that can influence this index. According to the literature, the values obtained are characteristic of bakery and pastry products: cupcake $-\mathrm{GI}=73 \pm 12$, croissant$\mathrm{GI}=67$, bread au lait $-\mathrm{GI}=63 \pm 10$, baguette-GI = $95 \pm 15$ [26].

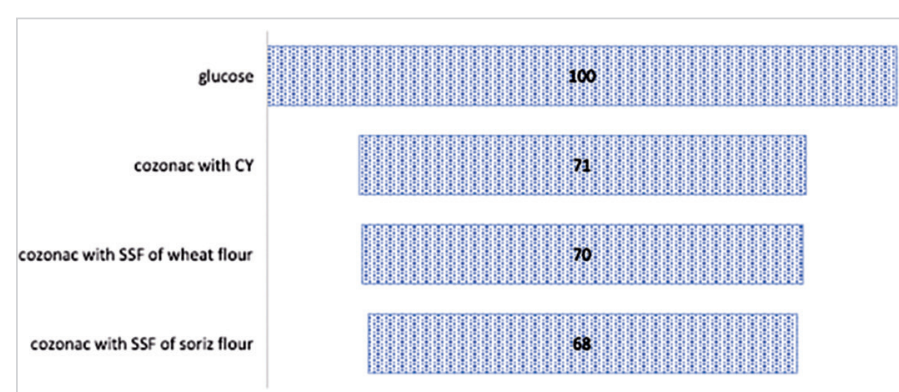

Figure 6. Glycemic index of cozonac samples

\subsection{Sensory indices}

As mentioned in the literature, any change in the technological process of obtaining cozonacs or in the development of the recipe can lead to changes in their quality. The volatile compounds in the kernel derive, in particular, from the fermentation process of SSF, from the oxidation of lipids in flour and, to a lesser extent, from the Maillard reaction, while the aroma of the crust is mainly due to the Maillard reaction. The sensory profiles of baked cozonacs were analyzed descriptively by the panel members (specialists from the Department of Food and Nutrition, Technical University of Moldova), assessing the intensity of each (Table 6) and a hedonic parameter - as a general assessment $[29,30]$.

Table 5

Evolution of glycemia after glucose and cozonac samples consumption

\begin{tabular}{|c|c|c|c|c|c|c|c|c|}
\hline \multicolumn{9}{|c|}{ Time, min } \\
\hline Sample & 0 & 15 & 30 & 45 & 60 & 90 & 120 & 180 \\
\hline \multicolumn{9}{|c|}{ Glycemia, mmol/1 } \\
\hline glucose & $3.8 \pm 0.8$ & $5.6 \pm 1.1$ & $6.8 \pm 1.2$ & $5.6 \pm 0.9$ & $4.5 \pm 0.7$ & $4,9 \pm 0.9$ & $4.4 \pm 0.6$ & $3.7 \pm 0.4$ \\
\hline cozonac with $\mathrm{CY}$ & $3.8 \pm 0.7$ & $4.8 \pm 0.8$ & $6.1 \pm 0.8$ & $5.2 \pm 0.2$ & $4.5 \pm 0.4$ & $4,3 \pm 0.4$ & $4.2 \pm 0.6$ & $4.1 \pm 0.6$ \\
\hline cozonac with SSF of wheat flour & $3.8 \pm 0.6$ & $4.8 \pm 0.6$ & $5.9 \pm 0.9$ & $5.0 \pm 0.4$ & $4.6 \pm 0.4$ & $4,4 \pm 0.4$ & $4.1 \pm 0.6$ & $4.1 \pm 0.6$ \\
\hline cozonac with SSF of soriz flour & $3.8 \pm 0.6$ & $4.9 \pm 0.8$ & $5.8 \pm 0.9$ & $5.5 \pm 1.0$ & $4.5 \pm 0.5$ & $4.2 \pm 0.5$ & $4.1 \pm 0.5$ & $4.0 \pm 0.5$ \\
\hline
\end{tabular}

Sensory descriptors used to describe separately the crumb and the crust of cozonac

Table 6

\begin{tabular}{|c|c|c|c|}
\hline \multicolumn{4}{|c|}{ Sensorial evaluation of cozonac crumb } \\
\hline Aspect & Smell & Taste & Structure \\
\hline Intensity of color & Cereals & Sweet & Elasticity \\
\hline Luminosity & Acetic acid & Acid & Deformability \\
\hline Density & Hay & Bitter & Resistance to chewing \\
\hline Porozity & Yeast & Cereals Flavor & Surface moistness \\
\hline \multirow[t]{4}{*}{ Homogeneity } & \multirow[t]{4}{*}{ Rancid } & Hay Flavor & Compactness \\
\hline & & Yeast flavor & Cohesiveness \\
\hline & & Astringent & Juiciness \\
\hline & & Aftertaste & \\
\hline
\end{tabular}

\begin{tabular}{|c|c|c|c|}
\hline \multicolumn{4}{|c|}{ Sensorial evaluation of cozonac crust } \\
\hline Aspect & Smell & Taste & Structure \\
\hline Intensity of colour & Intensity of smell & Sweet & Structure regularity \\
\hline Regularity of colour & Cereals & Acid & Hardness \\
\hline \multirow[t]{5}{*}{ Tonality of colour (yellow/brown) } & Fragrant & Bitter & Friability \\
\hline & Roasted & Hay flavor & Crispness \\
\hline & \multirow[t]{3}{*}{ Burned } & Yeast flavor & \multirow[t]{3}{*}{ Resistance to detachment (crust/crumb) } \\
\hline & & Astringent & \\
\hline & & Aftertaste & \\
\hline
\end{tabular}


The cozonacs obtained with different fermentation agents (CY, SSF with wheat flour, SSF with sorghum flour) were characterized by close sensory profiles. Cozonacs with SSF from sorghum flour had the weakest sensory profile in terms of structural characteristics, but the best aromatic profile. The wheat flour SSF cozonac showed optimal structural characteristics of the core and crust, and the CY cozonac, despite a good consistency, had an uneven crust both in color and structure. All cozonac samples were characterized by slightly acid taste, with specific, pleasant flavors.

\section{Conclusions}

$\square$ The tendencies of specialists in the field of producing with artisanal technologies are based on the use of local traditional raw materials, which give the products specific texture and sensory characteristics;

$\square$ The artisanal processes in the elaboration of cozonacs do not necessarily involve high quality flours, but they require increased amounts of fluids (water, milk etc.) and a long kneading (about 40 minutes) for the formation of the gluten network; $\square$ SSF is the key element in the development of artisanal products due to its ability to improve flavor and potential nutritional aspects;

$\square$ Fermentation is the fundamental process in obtaining cozonacs with SSF and is also characterized by specific time and temperature parameters;

$\square$ The parameters of the technological process, such as time, temperature and consistency influence the characteristics of the dough and, as a result, of the cozonac;

$\square$ The final product has a slightly acidic flavor, obtaining particular organoleptic properties, due to the production of metabolites (products of the metabolism of many microbial species present in SSF), which gives a more complete and richer aroma, but also a longer shelf life compared to industrial products;

$\square$ However, it seems that a long fermentation of the dough, even if CY is used as a fermenting agent, leads to the formation of quality indices of the dough and cozonac, very close to the products obtained only with SSF;

$\checkmark$ The use of SSF from sorghum flour would be an alternative in the development of gluten free bakery and pastry products using artisanal technologies.

\section{REFERENCES}

1. Regulation (EU) No $1151 / 2012$ of the European Parliament and of the Council of 21 November 2012 on quality schemes for agricultural products and foodstuffs. [Electronic resource: https://eur-lex.europa.eu/eli/ reg/2012/1151/oj Access date 14.07.2020]

2. Gobbetti, M. (1998). The Sourdough microflora, interaction of lactic acid bacteria and yeasts, Trends in Food Science and Technology, 9(7), 267-274. https://doi.org/10.1016/S0924-2244(98)00053-3

3. De Vuyst, L., Neysens, P. (2005). The sourdough microflora: Biodiversity and metabolic interactions. Trends in Food Science and Technology, 16(13), 43-56. https://doi.org/10.1016/j.tifs.2004.02.012

4. Finotti, M. (2018). Artisan bread between tradition and innovation. $\mathrm{PhD}$ thesis. Department of Agro-Food Sciences and Technologies, University of Bologna. [Electronic resource: https://amslaurea.unibo.it/19206/1/finotti_mara_tesi.pdf Access date 14.07.2020] (In Italian)

5. Siminiuc, R., Cosciug, L., Rubțov, S., Balan, I., Vidrasco, A. (2014). Ouality indexes of spontaneous flora sourdough of different flours. Proceedings International Conference "Modern technologies, in the food industry". DSpace repository. [Electronic resource: http://repository.utm.md/bitstream/ handle/5014/6861/MTFI 2014_pg287 292.pdf?sequence=1\&isAllowed=y Access date 14.07.2020]

6. Siminiuc, R., Chirsanova,A. (2018). Grain size distribution of sorghum oryzoidum flour. Proceedings International Conference "Modern technologies, in the food industry". DSpace repository. [Electronic resource: http://repository.utm.md/bitstream/handle/5014/3738/Conf_Tehnol_2018_pg320. pdf? sequence $=1$ \&isAllowed $=y$ Access date 01.09.2020] (In Romanian)

7. Soboleva, E.B., Sergacheva, E.S. (2013) Technology and organization of production of grain processing products, bakery and pasta. [Electronic resource: https://books.ifmo.ru/file/pdf/1414.pdf Access date 01.08.2020] (In Russian)

8. Siminiuc, R. (2014). Technological and nutritional aspects of gluten free products of soriz (Sorghum Oryzoidum). PhD thesis. Faculty of Food Technology, Technical University of Moldova. (In Romanian)

9. GOST 21094-75 "Bread and bakery products. Method for the determination of moisture" Moscow: Standartinform. 2002. -4 p. (In Russian)

10. GOST 5669-96 "Bakery products. Method for determination of porosity". Moscow: Standartinform. 2001. - 5 p. (In Russian)

11. GOST 10444.1 2-88 "Food products. Method for determination of yeast and mould”. Moscow: Standartinform. 2010. -10 p. (In Russian)

12. ISO 26642:2010 "Food products - Determination of the glycaemic index (GI) and recommendation for food classification”. Technical Committee: ISO/TC34 Food products. 2010. $-18 \mathrm{p}$.

13. Sudeash, J., Chauhan, B.M., Kapoor, A.C. (1989). Protein digestibility (in vitro) of chickpea and blackgram seeds as affected by domestic processing and cooking. Plant Foods for Human Nutrition, 39, 149-154. https://doi.org/10.1007/BF01091894

14. GOST ISO 6658-2016 "Sensory analysis. Methodology. General guidance”. Moscow: Standartinform. 2016. - 26 p. (In Russian)

15. Siminiuc, R., Coşciug, L., Bulgaru, V., Ştefîrţă, M. (2012). Glycaemic index of soriz (Sorghum oryzoidum) grains and groats. Proceedings International Conference "Modern technologies, in the food industry”. DSpace repository. [Electronic resource: http://repository.utm. $\mathrm{md} /$ bitstream/handle/5014/6254/Conf_MTFI_2012_Vol_2_pg132-135. pdf?sequence $=1$ \&isAllowed=y Access date 14.07.2020]
16. Biochemical analyzer STAT-FAX ${ }^{\oplus} 1904+$. User’s manual. Awareness Technology Inc. [Electronic resource: http://www.asta.ru/products/43/manual.pdf Access date 15.06.2020] (In Russian)

17. Brand-Miller, J., Foster Powell, K., McMillan, P. (2005). The Low GI Diet Revolution: The Definitive Science-Based Weight Loss PlanNew York: Da Capo Lifelong Books. - 320 p. ISBN1-56924-413-8

18. Leonte, M. (2000). Biochemistry and Bakery Technology. Ed. Crigarux, Piatra -Neamt - 452 p; ISBN973-99316-3-4 (In Romanian)

19. Mion, C. The evaluation of the shelf-life of artisan Panettone. Thesis 2015. Universita di Pisa. [Electronic resource: https://core.ac.uk/download/pdf/79618731.pdf Access date 20.07.2020] (In Italian)

20. Esteve, C.C., De Barber, C.B., Martínez-Anaya, M.A. (1994). Microbial sour doughs influence Acidification properties and breadmaking potential of wheat dough. Journal of Food Science, 59(3), 629-633. https://doi. org/10.1111/j.1365-2621.1994.tb05579.x

21. Corsetti, A., Settanni, L. (2007). Lactobacilli in sourdough fermentation. Food Research International, 40(5), 539-558. https://doi.org/10.1016/j. foodres.2006.11.001

22. Damiani, P., Gobbetti, M., Cossignani, L., Corsetti, A., Simonetti, M.S., Rossi, J. (1996). The sourdough microflora. Characterization of hetero- and homofermentative lactic acid bacteria, yeasts and their in teractions on the basis of the volatile compounds produced. $L W T-$ Food Science and Technology, 29(1-2), 63-70. https://doi.org/10.1006/ fstl.1996.0009

23. Hur, S.J., Lim, B.O., Decker, E.A., McClements, D.J. (2011). In vitro human digestion models for food applications. Food Chemistry, 125(1), 1-12. https://doi.org/10.1016/j.foodchem.2010.08.036

24. Lopez, H.W., Krespine, V., Guy, G., Messager, A., Demigne, C., Remesy, C. (2001). Prolonged fermentation of whole wheat sourdough reduces phytate level and increases soluble magnesium. Journal of Agricultural and Food Chemistry, 49(5), 2657-2662. https://doi.org/10.1021/jf001255z

25. Di Cagno, R., De Angelis, M., Lavermicocca, P., De Vincenzi, M., Giovannini, C., Faccia, M., Gobbetti, M. (2002). Proteolysis by sourdough lactic acid bacteria: effect on wheat flour protein fractions and gliadin peptides involved in human cereal intolerance. Applied and Environmental Microbiology, 68(2), 623-633. https://doi.org/10.1128/AEM.68.2.623633.2002

26. Foster-Powell, K., Holt, S.H.A., Brand-Miller, J.C. (2002). International table of glycemic index and glycemic load values: 2002. The American Journal of Clinical Nutrition, 76(1), 5-56. https://doi.org/10.1093/ ajcn/76.1.5

27. Korem, T., Zeevi, D., Zmora, N, Weissbrod, O., Bar, N., Lotan-Pompan, M., Avnit-Sagi, T., Kosower, N, Malka, G., Rein, M., Suez, J., Goldberg, B.Z., Weinberger, A., Levy, A.A., Elinav, E., Segal1, E. (2017). Bread affects clinical parameters and induces gut microbiome-associated personal glycemic responses. Cell Metabolism, 25(6), 1243-1253.e5. https://doi. org/10.1016/j.cmet.2017.05.002

28. Virlan, A., Coşciug, L., Siminiuc, R. (2018). Influence of the liquid phase composition on the glycemic index of boiled rice. Proceedings International Conference "Modern technologies, in the food industry". DSpace repository. [http://repository.utm.md/bitstream/handle/5014/3680/ Conf_Tehnol_2018_pg115_118.pdf?sequence=1 \&isAllowed=y Access date 14.07.2020] 
29. Czerny, M., Schieberle, P. (2002). Important aroma compounds in freshly ground wholemeal and white wheat flour-identification and quantitative changes during sourdough fermentation. Journal of Agricultural and Food Chemistry,50(23), 6835-6840. https://doi.org/10.1021/jf020638p
30. Venturi, F., Sanmartin, C., Taglieri, I., Nari, A., Andrich, G., Zinnai, A (2016). Effect of the baking process on artisanal sourdough bread-making: A technological and sensory evaluation. Agrochimica, 60(3), 222234. https://doi.org/10.12871/00021857201635

\section{AUTHOR INFORMATION}

Rodica Siminiuc - doctor, associate professor, Department of Food and Nutrition, Head of doctoral and postdoctoral department, Technical University of Moldova. 168, Stefan cel Mare Bd., Chisinau, Republic of Moldova. Tel.:+373-69-579-120, E-mail: rodica.siminiuc@adm.utm.md ORCID: https://doi.org/0000-0003-4257-1840 *corresponding author

Dinu Turcanu - Vice-Rector for Informatization, Partnerships, Institutional Image and Communication, Technical University of Moldova. 168, Stefan cel Mare Bd., Chisinau, Republic of Moldova. Tel.: +373-68-302-020, E-mail: dinu.turcanu@adm.utm.md ORCID: https://doi.org/0000-0001-5540-4246

All authors bear responsibility for the work and presented data.

All authors made an equal contribution to the work.

The authors were equally involved in writing the manuscript and bear the equal responsibility for plagiarism.

The authors declare no conflict of interest.

Received 12.08.2020 Accepted in revised 03.09.2020 Accepted for publication 25.09.2020 